\title{
VERBAL EMBODIMENT OF THE ENGLISH CONCEPT GENIUS
}

\section{Strochenko L. V.}

\section{INTRODUCTION}

In her work "The Genius in History: Historiographic Explorations" in The Wiley handbook of genius Laura C. Ball claims: "We consume autobiographies, biographies, films, histories, and academic theories of the outliers, the heroes, the Great Men, the geniuses. They are historical celebrities. We are captivated by them, their lives, and their work, but also their stories provide readers with a source of affiliation and inspiration. Yet, despite the attention given to their seemingly inevitable greatness, these celebratory histories tell us little about why they are considered to be great" .

The present paper is an attempt to disprove the above mentioned statement by showing that discourse analysis is an effective way of learning verbal representation of a phenomenon as well as the phenomenon itself. Thus the aim of the present paper is to analyze verbal embodiment of the concept under study by means of singling out conceptual features of GENIUS foregrounded in the English speech.

In a historical perspective, the term genius is rather problematic: it has had a long history of use, and has acquired multiple meanings, describing vastly different phenomena. The first known instance of the term genius being used in the English language is during the Roman Empire, where it referred to a male spiritual protector or a guardian spirit. Typically, the protection offered by a genius was applied to individuals, families, and physical spaces. Every person, family, city, body of water, or other important physical structure had its own genius. In addition, a genius could also refer to the "spirit of the times" or zeitgeist. Over time, genius became more intimately connected with individuals. However, it was not until the Enlightenment when the connotations of the word obtained its present implications: genius referring to the superior or unique abilities of an individual person. In the second half of the XVIII century there was a turning point in the semantics of this lexical unit. Since then, genius has denoted not only a special ability, but also a person who has such

\footnotetext{
${ }^{1}$ Ball L.C. The Genius in History: Historiographic Explorations. The Wiley handbook of genius. Oxford : Wiley Blackwell, 2014. P. 3-19.
} 
quality. That is when there appeared numerous researches, which gave impetus to further study of this phenomenon ${ }^{2}$.

Among main trends in the study of the phenomenon of genius are: irrational approach, which emphasizes the divine nature of genius and is closely related to archaic and religious ideas; rational approach, within which genius is seen as the innate quality of a person, which makes it possible to clarify genius as a property of the human mind and to study it in different directions in psychology and genetics, as well as to determine biological (instincts, memory, genetic heredity, innate abilities to creativity) and psychological (fantasy, imagination, inspiration, spontaneity) factors of genius; empirical approach, according to which genius is the acquired property of a person in the process of his/her development; socio-cultural approach, which considers the significance and, at the same time, problematic interaction of a genius and society ${ }^{3}$.

The theoretical premises of the given paper are the basics of semanticcognitive approach to the study of concepts. According to the representatives of the semantic-cognitive approach, concept is a basic unit of human mental code, which has an internal structure consisting of conceptual features. Any concept presents the result of the individual and social cognizing of the world. Conceptual features contain comprehensive information about the corresponding object or phenomenon, as well as the interpretation of information of public consciousness and the treatment of the subject or phenomenon ${ }^{4}$.

The above mentioned linguistic trend treats language as one of the main tools of cognition and conceptualization of the world. To examine a concept through the language is the most reliable way of linguistic analysis which allows to detect its conceptual features and to work out the model of the concept. The structure of a concept is manifested through dictionary definitions of the corresponding lexical units (the name of the concept and its synonyms) and through speech contexts.

Analyzing various approaches to the study of concepts, A.P. Martyniuk notes, in particular, that the study of the verbalized concept is based on the onomasiological approach, which involves defining the linguistic means that objectify it, the fullest possible description of the semantics of these units and modeling the meaning of the concept as a global mental unit through its national originality. Componential analysis, etymological

\footnotetext{
${ }^{2}$ Ball L.C. The Genius in History : Historiographic Explorations. The Wiley handbook of genius. Oxford : Wiley Blackwell, 2014. P. 3-19.

3 Хомченкова Е.А. Феноменология гениальности : от антропной к социокультурной детерминации : Автореф. дис ... канд. філос. наук : 09.00.13. Омск, 2007. 20 с.

4 Попова З.Д., Стернин И.А. Семантико-когнитивный подход как направление когнитивной лингвистики. Vita in lingua: К юбилею профессора С.Г. Воркачева: Сборник статей / отв. ред. В.И. Карасик. Краснодар : Атриум, 2007. С. 171-180.
} 
analysis, identification of synonyms of the lexeme which names the corresponding concept and the study of ways of conceptualization as secondary reinterpretation, for example in aphorisms, are the main methods of any conceptual analysis ${ }^{5}$.

The speech embodiment of the concept under study is being considered on the basis of English artistic and publicist texts.

\section{Conceptual features of GENIUS in the English artistic and publicist discourse}

The research singles out conceptual features of the analyzed concept in the novel "Matilda" by Roald Dahl', in popular-science biographies of geniuses and in articles in the journal National Geographic. The novel "Matilda" was first published in 1988 and is considered one of the most popular books by the Roald Dahl.

The protagonist, Matilda Wormwood, a five-year-old prodigy, whose parents treat her with disdain, resorts to pranks like gluing her father's hat to his head etc, to get revenge on her parents (particularly her father) for being so mean to her. Matilda has read a variety of books by different authors, especially at the age of four, when she read many in six months.

The novel starts with the narrative compositional form argumentation where the narrator presents his viewpoints on parents' attitude to their children's intellectual and creative abilities. He claims that most often parents overestimate these abilities, considering their absolutely unworthy child a genius:

"It's a funny thing about mothers and fathers. Even when their own child is the most disgusting little blister you could ever imagine, they still think that he or she is wonderful. Some parents go further. They become so blinded by adoration they manage to convince themselves their child has qualities of genius. Well, there is nothing very wrong with all this. It's the way of the world. It is only when the parents begin telling us about the brilliance of their own revolting offspring, that we start shouting, "Bring us a basin! We're going to be sick!'”.

Rarely, as the narrator points out, there are parents who are not at all interested in their children, which is much worse than the previous case. These are the parents of the little girl Matilda who couldn't wait for their daughter to grow up and be thrown out of their lives:

"Occasionally one comes across parents who take the opposite line, who show no interest at all in their children, and these of course are far

\footnotetext{
5 Мартинюк А.П. Перспективи дискурсивного напрямку дослідження концептів. Вісник Харківського національного університету імені В.Н. Каразіна. Харків : ХНУ імені В.Н. Каразіна, 2009. № 837. С. 14-18.

${ }^{6}$ Roald Dahl. Matilda. URL: http://jssisdubai.com/document/uploaded/matilda.pdf
} 
worse than the doting ones. Mr. and Mrs. Wormwood were two such parents. They had a son called Michael and a daughter called Matilda, and the parents looked upon Matilda in particular as nothing more than a scab. A scab is something you have to put up with until the time comes when you can pick it off and flick it away. Mr. and Mrs. Wormwood looked forward enormously to the time when they could pick their little daughter off and flick her away, preferably into the next county or even further than that".

With the help of antithesis and graphical stylistic device of change of print - italics - the author emphasizes all the awfulness of this attitude towards the girl, who has extraordinary abilities:

"It is bad enough when parents treat ordinary children as though they were scabs and bunions, but it becomes somehow a lot worse when the child in question is extra-ordinary, and by that I mean sensitive and brilliant. Matilda was both of these things, but above all she was brilliant. Her mind was so nimble and she was so quick to learn that her ability should have been obvious even to the most half-witted of parents. But Mr. and Mrs. Wormwood were both so gormless and so wrapped up in their own silly little lives that they failed to notice anything unusual about their daughter. To tell the truth, I doubt they would have noticed had she crawled into the house with a broken leg".

This excerpt foregrounds the conceptual feature of extraordinary intellectual ability in the structure of the concept under study, which is verbalized by such nominative units: extraordinary, brilliant, quick to learn.

Another conceptual feature - young age - can be also singled out in the next excerpt. The narrator repeatedly states that Matilda's speech was impeccable and her vocabulary was equal to that of an adult:

"Matilda's brother Michael was a perfectly normal boy, but the sister, as I said, was something to make your eyes pop. By the age of one and a half her speech was perfect and she knew as many words as most grownups. The parents, instead of applauding her, called her a noisy chatterbox and told her sharply that small girls should be seen and not heard".

However, the girl's parents found only negative aspects of this situation and wanted her to remain silent.

By the age of three, Matilda had learned to read, and at four she could read fairly quickly:

"By the time she was three, Matilda had taught herself to read by studying newspapers and magazines that lay around the house. At the age of four, she could read fast and well and she naturally began hankering after books. The only book in the whole of this enlightened household was 
something called Easy Cooking belonging to her mother, and when she had read this from cover to cover and had learnt all the recipes by heart, she decided she wanted something more interesting".

At the age of four, Matilda went to the local library daily, where she read all books, first books for children, and later the world classics Dickens, Hemingway, etc.:

"From then on, every afternoon, as soon as her mother had left for bingo, Matilda would toddle down to the library. The walk took only ten minutes and this allowed her two glorious hours sitting quietly by herself in a cozy corner devouring one book after another. When she had read every single children's book in the place, she started wandering round in search of something else".

It was in the books that she found consolation, only in the world of literature she did not feel alone:

"These books gave Matilda a hopeful and comforting message: You are not alone".

The parents' indifferent and disrespectful attitude not only disturbed the girl, it encouraged her to take a kind of revenge. Matilda came up with different ways to punish her parents: substitute Dad's hair gel for his mother's paint, pour super-glue on his hat, and so on:

"Matilda longed for her parents to be good and loving and understanding and honourable and intelligent. The fact that they were none of these things was something she had to put up with. It was not easy to do so. But the new game she had invented of punishing one or both of them each time they were beastly to her made her life more or less bearable. Being very small and very young, the only power Matilda had over anyone in her family was brain-power. For sheer cleverness she could run rings around them all".

As we can see from the given passage, it foregrounds not only the conceptual feature of extraordinary intellectual abilities, but also the associative features of suffering and vindictiveness. The girl wanted to find a friend, a person who would understand her and treat her well:

"Sometimes Matilda longed for a friend, someone like the kind, courageous people in her books".

She found such a friend in the person of her first teacher, Miss Honey, as she had appreciated Matilda's abilities at the first meeting and supported her in every possible way. Miss Honey eventually replaces the girl's mother. When Matilda's parents decide to leave the country, she asks to leave the girl with her, to which the parents gladly agree. Thus, the prodigy girl finally got a chance for a better life. 
The analysis enabled singling out the following conceptual features of the concept GENIUS on the material of the analyzed novel: young age, extraordinary intellectual ability; suffering and vengeance.

Verbal embodiment of the concept under study in the English speech has been also analyzed on the material of biographies and articles in National Geographic ${ }^{7}$, the official magazine of the National Geographic Society which focuses on geography, world history, culture etc.

In modern linguistics, several types of biographies are distinguished, among which are academic, artistic, documentary and popular scientific ${ }^{8}$.

The given study focuses on the popular scientific biographies of such generally recognized geniuses as Leonardo da Vinci ${ }^{9}$, Isaac Newton ${ }^{10}$, Albert Einstein ${ }^{11}$ and Wolfgang Amadeus Mozart ${ }^{12}$. The target audience of these publications is the average naïve native speaker, so the analysis of their linguistic peculiarities will enable singling out conceptual features of the concept GENIUS in the English naive picture of the world.

The investigated popular scientific biographies foreground, first of all, the conceptual feature prominence / extraordinariness. The corresponding examples can be found in the first lines of the analyzed biographies:

"Isaac Newton (January 4, 1643 to March 31, 1727) was a physicist and mathematician who developed the principles of modern physics, including the laws of motion, and is credited as one of the great minds of the 17th century Scientific Revolution"; "And because other Newton scholars have defaulted on the task of evaluating Newton's motives, such "suggestions" have stood unchallenged and unrefuted to this day-coloring the legacy and tainting the name of one of history's greatest scientists".

His work is graded as the most influential in the sphere of physics and in science in general: "It is said to be the single most influential book on physics and possibly all of science. Its publication immediately raised Newton to international prominence".

His contemporaries called his abilities extraordinary, and the scientist himself - the most prominent genius in the history of mankind: "In August 1669, Barrow identified its author to Collins as "Mr. Newton... very young... but of an extraordinary genius and proficiency in these things"; "Isaac Newton's fame grew even more after his death, as many of his contemporaries proclaimed him the greatest genius who ever lived".

\footnotetext{
${ }^{7}$ Genius : articles. URL:

https://www.nationalgeographic.com/search?q=genius

${ }^{8}$ Ефремова Д.А. Типы англоязычных биографий второй половины XX - начала ХХІ века. Филология и культура. 2013. № 1 (32). С. 142-145.

${ }^{9}$ Leonardo da Vinci. URL: http://www.biography.com/people/leonardo-da-vinci-40396\#the-last-supper

${ }^{10}$ Isaac Newton. URL: https://www.biography.com/news/isaac-newton-biography-facts

${ }_{11}$ Albert Einstein. URL: http://www.notablebiographies.com/Du-Fi/Einstein-Albert.html\#ixzz4WVvnakf8

${ }^{12}$ Wolfgang Amadeus Mozart. URL: https://www.biography.com/people/wolfgang-mozart-9417115
} 
In the biographies of Leonardo da Vinci the given feature is verbalized with the help of such lexical units as leading, great:

"Leonardo da Vinci (1452-1519) is one of the world's greatest thinkers, artists and philosophers"; "Leonardo da Vinci was a leading artist and intellectual of the Italian Renaissance who's known for his enduring works "The Last Supper" and "Mona Lisa."”.

An interesting, however, unreliable fact of his biography is the reaction of his teacher, the artist Verrocchio, to the abilities of the student. He was so impressed with the works of da Vinci, that he gave up painting:

"According to "Lives of the Most Excellent Painters, Sculptors and Architects", written around 1550 by artist Giorgio Vasari, Verrocchio was so humbled by the superior talent of his pupil that he never picked up a paintbrush again".

This context also verbalizes the feature of extraordinary creativity. The next conceptual feature, which is verbalized in these biographies, is intellectual ability. For example, Newton's uncle insisted on his entering the university, understanding his innate mental abilities:

"Perhaps sensing the young man's innate intellectual abilities, his uncle, a graduate of the University of Cambridge's Trinity College, persuaded Newton's mother to have him enter the university".

The lexical unit leading in this fragment also underlines his extraordinary intellect:

"It also cemented his position as one of the leading minds of his age".

The conceptual feature intellect can be also verbalized with the help of nominative units inventive, curious, keen:

"Using his inventive mind, da Vinci sketched war machines such as a war chariot with scythe blades mounted on the sides, an armored tank propelled by two men cranking a shaft and even an enormous crossbow that required a small army of men to operate"; "Possessor of a curious mind and keen intellect, da Vinci studied the laws of science and nature, which greatly informed his work as a painter, sculptor, architect, inventor, military engineer and draftsman".

As for the biography of Wolfgang Amadeus Mozart, they are characteristic of the widespread use of the nominative unit prodigy and its derivative prodigious:

"The composer". Wolfgang Amadeus Mozart (1756-1791) led a life that was dramatic in many respects, including his career as a child prodigy, his struggle to achieve personal independence and establish a career, his brushes with financial disaster, and his death in the course of trying to complete his Requiem"; "Born in In Salzburg, he showed prodigious ability from his earliest childhood. Already competent 
on keyboard and violin, he composed from the age of five and performed before the European royalty".

In addition, the age in which he achieved success is strongly emphasized: "Mozart wrote his first symphony when he was eight years old".

Thus, the conceptual feature age of the investigated concept is foregrounded by such lexical units as the earliest childhood, the age of five, eight years old.

The extraordinary talent of Mozart is emphasized, in particular, in the memoirs of his sister who wrote that their father began teaching little Amadeus to play as an entertainment, but the boy showed unusual abilities:

"In the fourth year of his age, his father, for a game, as it was, began to teach him a few minutes and pieces at the clavier... He could play it faultlessly and with the greatest delicacy, and keeping exactly in time.... At the age of five, he was already composing small pieces, which he played to his father who wrote them down".

The feature of extraordinary giftedness is also emphasized by the fact that the little boy became a composer before he could write down his own compositions, and his father was doing it for him for some time. Mozart's success became such a big surprise to his father and teacher at the same time that he even ceased to write music himself:

"In his early years, Wolfgang's father was his only teacher. There is evidence that Mozart was keen on progress beyond what he was taught. It came as a surprise to Leopold, who eventually gave up composing when his son's musical talent became evident".

A similar example of hyperbolized actualization of the conceptual feature of extraordinary creative abilities is registered in the investigated biography of Leonardo da Vinci.

The conceptual feature originality can also be singled out on the material of the studied biographies:

"Sometimes called the father of modern science, Isaac Newton revolutionized our understanding of our world"; "Long before his breakthrough work Philosophiae Naturalis Principia Mathematica was published, Newton was considered one of England's leading thinkers".

Another interesting fact is that Albert Einstein believed that Isaac Newton was ahead of his time, which also foregrounds novelty as a conceptual feature of the concept under study:

"Einstein credited Isaac Newton, the father of physics and arguably the founder of scientific certainty, with "the greatest advance in thought that a single individual was ever privileged to make." The compliment is not hyperbole: In his Principia and the discoveries that preceded it, 
Newton single-handedly deciphered more of the universe's enigmas than perhaps any other scientist in history. He revolutionized mathematics, integrated the previously disparate fields of mechanics and astronomy, and thus opened the door to the science of force and motion as we know it".

The biography of Leonardo da Vinci also underlines that he was ahead of his time and even prophesized the future:

"A man ahead of his time, da Vinci appeared to prophesize the future with his sketches of machines resembling a bicycle, helicopter and a flying machine based on the physiology of a bat"; "In several different fields, from science to astronomy, he proved to be both innovative and several centuries ahead of his contemporaries".

The conceptual feature of originality is often verbalized by the lexical unit pioneer, which foregrounds the fact that da Vinci was the first to use certain techniques in painting etc:

"His painting of the "Virgin of the Rocks," begun in 1483, demonstrated his pioneering use of chiaroscuro - a stark contrast between darkness and light that gave a three-dimensionality to his figures and sfumato - a technique in which subtle gradations, rather than strict borders, infuse paintings with a softer, smoky aura"; "He also pioneered the use of Chiaroscuro".

Lexical unit invent also foregrounds the conceptual feature of novelty: "He 'invented' the bicycle, airplane, helicopter, and parachute some 500 years ahead of their time".

The wide range of interests and trends of da Vinci's works is underlined with the help of hyperbole in the following fragment: "There seemed to be no limit in the scope of his interest and work".

The artist's works are considered valuable as a part of human culture:

"Today, the "Mona Lisa" hangs in the Louvre Museum in Paris, France, secured behind bulletproof glass and regarded as a priceless national treasure seen by millions of visitors each year".

Thus, the following conceptual features of GENIUS have been singled out in the naïve picture of the world (on the material of the analyzed biographies): extraordinariness (greatest, extraordinary), intellect (innate intellectual abilities, leading mind), creative abilities (keen on progress beyond what he was taught), age (early childhood), originality (breakthrough, advance in thought), value of the results of his work (priceless treasure).

Informative and appealing functions of publicist functional style found their reflection in the headlines of the studied articles in National Geographic, for example, What makes a genius?, What made Leonardo da Vinci a genius? Can you name these 13 geniuses?, Do you have the traits 
of a genius?. Interrogative form of the headlines intensifies attracting of the readers' attention.

First of all, the conceptual feature extraordinariness is verbalized here with the help of such lexical units as exceptional, rare, soar above the rest of us, stood out:

"Some minds are so exceptional they change the world. We don't know exactly why these people soar above the rest of us, but science offers us clues"; "Throughout history rare individuals have stood out for their meteoric contributions to a field".

The next conceptual feature - novelty, originality - is verbalized here with the help of lexical units revolutionized, changing the world, scientific breakthroughs:

"Einstein revolutionized our understanding of the very laws of the universe"; "Instead we can try to understand it by unraveling the complex and tangled qualities - intelligence, creativity, perseverance, and simple good fortune, to name a few - that entwine to create a person capable of changing the world"; "Scientific breakthroughs like Darwin's theory of evolution by natural selection would be impossible without creativity, a strand of genius that Terman couldn't measure".

Besides, these fragments mention other features of GENIUS intellect, creativity, perseverance.

An interesting explanation of the nature of GENIUS is offered in the following excerpt, according to which the phenomenon of genius is closely connected with the diversity of a person's interests:

"In all those books, I've noticed that creativity comes from connecting art to science. To be really creative, you have to be interested in all sorts of different disciplines rather than be a specialist. Being curious about everything and curious just for curiosity's sake, not simply because it's useful, is the defining trait of Leonardo".

Such conceptual features as creativity and curiosity can be singled out in the given fragment.

But to become a genius it is necessary to realize one's potential which feature is verbalized by the lexical units: achievement, contributions:

"But monumental intelligence on its own is no guarantee of monumental achievement, as Terman and his collaborators would discover". "Throughout history rare individuals have stood out for their meteoric contributions to a field".

The irrational approach to the nature of genius is reflected in the following conceptual feature, namely: the unknown power, as in the case of a well-known jazz pianist who cannot explain his emotional and psychological state during the performance: 
"This may help explain the astounding performances of jazz pianist Keith Jarrett. Jarrett, who improvises concerts that last for as long as two hours, finds it difficult-impossible, actually-to explain how his music takes shape. But when he sits down in front of audiences, he purposefully pushes notes out of his mind, moving his hands to keys he had no intention of playing. "I'm bypassing the brain completely," he tells me. "I am being pulled by a force that I can only be thankful for".

The importance of socio-cultural component in the development of a genius is foregrounded in the following context with the help of lexical units: nurture, social and cultural influences:

"Genetic potential alone does not predict actual accomplishment. It also takes nurture to grow a genius. Social and cultural influences can provide that nourishment, creating clusters of genius at moments and places in history: Baghdad during Islam's Golden Age, Kolkata during the Bengal Renaissance, Silicon Valley today".

Thus, the analysis of artistic and publicist texts enabled singling out the following verbalized conceptual features of GENIUS in the English image of the world: extraordinariness; originality; creativity, curiosity; intellect; achievement; an unknown force; socio-cultural influence; young age; suffering and vengeance.

\section{Conceptual metaphor in the structure of the concept GENIUS}

Aphorism is defined as a short original statement, a generalized, deep thought, expressed in a concise form, sometimes unexpectedly paradoxical $^{13}$.

During the study, 100 English aphorisms with the genius component have been analyzed ${ }^{14}$. It has been established that several models of the conceptual metaphor are realized in these expressions.

Let us first consider theoretical aspect of this linguistic phenomenon. Conceptual metaphor is one of the most important terms in cognitive linguistics, which refers to the process of establishing cognitive links between several concepts or conceptual structures, belonging to different domains. Metaphor is "understanding and experiencing one kind of thing in terms of another"

Unlike the traditional linguistic approach to metaphor, conceptual metaphor, as G. Lakoff sees it, represents a universal quality of thinking. Conceptual metaphor does not belong to the language only, it can be

\footnotetext{
${ }^{13}$ Словник літературознавчих термінів. URL: https://ukrlit.net/info/dict/5yef1.html

${ }^{14}$ Genius. URL: https://www.brainyquote.com/topics/genius

15 Лакофф Д., Джонсон М. Метафоры, которыми мы живем : Пер. с англ. Теория метафоры. Сборник. М. : Прогресс, 1990. С. 387-415.
} 
expressed both by verbal and non-verbal means - arts, music, gestures, etc. So metaphor is a cognitive process that is reflected in language structures.

According to Lakoff and Johnson's Theory, conceptual metaphor represents interaction of two cognitive structures (or domains): the source domain and the target domain. The target domain is structured similarly to the source domain, i.e. metaphorical correspondences or, in other words, metaphorical mappings are established between them ${ }^{16}$.

The linguists claim that our primary metaphorical systems are grounded first and foremost in our direct physical and social experience. All basic sensorimotor concepts are literal, in the sense that they are directly abstracted from physical interaction with the environment. The experiences of dimensionality, orientation, size, etc. form a system of literal concepts, which then form the basis for metaphoric concepts. The claim that metaphors exist as correlations between abstract concepts and embodied experience and that verbal metaphors are merely surface-level manifestations of underlying conceptual metaphors is most clear with metaphors that map abstract concepts on to direct physical experiences ${ }^{17}$.

This type of metaphor is aimed at verbalizing concepts such as life, death, love, happiness, etc., which belong to complex mental spaces that are not directly observable and in the process of cognition relate to simpler mental spaces that are observed directly.

As Kövecses suggests, "conceptual metaphor will continue to play a key role in the development of cognitive linguistics as a general study of language (as well as several other disciplines outside linguistics), as we keep discovering its extensive presence at all levels of linguistic description and its important contribution to connecting mind with the body, language with culture, body with culture, and language with the brain" $" 18$.

It has been established that several models of the conceptual metaphor are realized in the studied aphorisms, in particular, GENIUS IS MADNESS represented in such aphorisms as:

"There is no great genius without some touch of madness" (Aristotle); "Imperfection is beauty, madness is genius and it's better to be absolutely ridiculous than absolutely boring" (Marilyn Monroe);

"Genius is one of the many forms of insanity" (Cesare Lombroso).

It should be noted that the association of genius with madness is one of the quite common theories of the nature of this phenomenon.

\footnotetext{
${ }^{16}$ Conceptual metaphor. URL: http://scodis.com/for-students/glossary/conceptual-metaphor/

${ }^{17}$ Ritchie L.D. Conceptual Metaphor Theory. Context and Connection in Metaphor. Palgrave Macmillan, London. URL: https://link.springer.com/chapter/10.1057/9780230286825_3

18 Kövecses, Zoltán. Conceptual metaphor theory. URL: https://www.researchgate.net/publication/ 311403391_Conceptual_metaphor_theory/citation/download
} 
The next conceptual metaphor - GENIUS IS WORK - emphasizes the importance of work, the efforts presented by geniuses for their achievements, for example,

"Genius is one percent inspiration and ninety-nine percent perspiration" (Thomas A. Edison);

"The only genius that's worth anything is the genius for hard work" (Kathleen Winsor);

"If you knew how much work went into it, you wouldn't call it genius" (Michelangelo Buonarroti).

Ascribed to the ingenious scientist's ability to make complex things accessible to the understanding of ordinary people is reflected in the conceptual metaphor GENIUS IS SIMPLE, for example:

"A genius is someone who takes a complex thing and makes it look simple. An academic does the opposite" (Robert Fanney);

"Any fool can make something complicated. It takes a genius to make it simple" (Woody Guthrie);

"The role of genius is not to complicate the simple, but to simplify the complicated" (Criss Jami).

The following comparisons of genius with talent contain the indication that real genius is almost unattainable as the sun. Thus conceptual metaphor GENIUS IS FIRE is realized here:

"Talent is a flame. Genius is a fire" (Bernard Williams);

"The true artist is not proud: he unfortunately sees that art has no limits; he feels darkly how far he is from the goal, and though he may be admired by others, he is sad not to have reached that point to which his better genius only appears as a distant, guiding sun" (Ludwig van Beethoven).

Conceptual metaphor GENIUS IS PRECIOUS is realized in comparison of genius without education with silver in a mine: Franklin).

"Genius without education is like silver in the mine" (Benjamin

The last of the distinguished conceptual metaphors GENIUS IS ENEMY reflects the difficult relationship of a genius with society, which is quite often hostile to people with extraordinary abilities:

"When a great genius appears in the world you may know him by this sign; that the dunces are all in confederacy against him" (Jonathan Swift);

"The public is wonderfully tolerant. It forgives everything except genius" (Oscar Wilde);

"Genius inspires resentment. A sad fact of life" (Eoin Colfer);

"In the republic of mediocrity, genius is dangerous" (Robert G. Ingersoll). 
As we see, these aphorisms are based on the opposition of average personalities to geniuses.

Thus several conceptual metaphors have been singled out on the basis of the studied material. They foreground different associative features of the English concept GENIUS.

\section{CONCLUSIONS}

Concept is a basic unit of human mental code, which has an internal structure consisting of conceptual features; it is the result of the individual and social cognizing of the world. The study of any concept through the language is the most reliable way of linguistic analysis which allows to detect conceptual features and to work out the structural model of the concept. The structure of a concept is manifested through dictionary definitions of the corresponding lexical units and through speech contexts.

The verbal embodiment of the concept GENIUS in the English speech was considered on the basis of English artistic and publicist discourse.

The analysis of the verbal embodiment of the concept under study in artistic discourse enabled singling out the following conceptual features of the concept GENIUS: young age, extraordinary intellectual ability; suffering and vengeance.

The analysis of publicist texts enabled singling out the following verbalized conceptual features of GENIUS in the English image of the world: extraordinariness; originality; creativity, curiosity; intellect; achievement; an unknown force; socio-cultural influence.

Conceptual metaphor is the main means of the conceptual system of a person by which we understand and perceive one type of objects in terms of objects of another type. The study of the English aphorisms with the component genius made it possible to single out several conceptual metaphors, in particular, GENIUS IS MADNESS, GENIUS IS FIRE, GENIUS IS WORK, GENIUS IS PRECIOUS, GENIUS IS ENEMY, GENIUS IS SIMPLE. They foreground corresponding associative features of the English concept GENIUS.

The prospect of further research is seen in consideration of the verbal embodiment of concept GENIUS in the English scientific discourse which will enable modeling the structure of the concept in the English professional image of the world.

\section{SUMMARY}

The article is dedicated to the investigation of the peculiarities of verbal embodiment of the concept GENIUS in the English speech. The research singles out conceptual features of the analyzed concept in the 
English artistic and publicist discourse. The research has been done on the basis of the novel "Matilda" by Roald Dahl, biographies of geniuses, articles about geniuses in National Geographic and English aphorisms with the component genius. The analysis of the verbal embodiment of the concept under study in artistic discourse enabled singling out the following conceptual features of the concept GENIUS: young age, extraordinary intellectual ability; suffering and vengeance. The analysis of publicist texts enabled singling out the following verbalized conceptual features of GENIUS in the English image of the world: extraordinariness; originality; creativity, curiosity; intellect; achievement; an unknown force; sociocultural influence. The study of the English aphorisms with the component genius made it possible to single out several conceptual metaphors, in particular, GENIUS IS MADNESS, GENIUS IS FIRE, GENIUS IS WORK, GENIUS IS PRECIOUS, GENIUS IS ENEMY, GENIUS IS SIMPLE which foreground corresponding associative features of the English concept GENIUS.

\section{REFERENCES}

1. Ефремова Д.А. Типы англоязычных биографий второй половины XX - начала XXI века. Филология и культура. 2013. № 1 (32). C. 142-145.

2. Лакофф Д., Джонсон М. Метафоры, которыми мы живем: Пер. с англ. Теория метафоры. Сборник. М.: Прогресс, 1990. С. 387-415.

3. Мартинюк А.П. Перспективи дискурсивного напрямку дослідження концептів. Вісник Харківського національного університету імені В.Н. Каразіна. - Харків: ХНУ імені В.Н. Каразіна, 2009. № 837. С. 14-18.

4. Попова 3.Д. Семантико-когнитивный подход как направление когнитивной лингвистики. Vita in lingua: $K$ юбилею профессора С.Г. Воркачева: Сборник статей / отв. ред. В.И. Карасик. Краснодар: Атриум, 2007. С. 171-180.

5. Словник літературознавчих термінів. - [Електронний ресурс]. Режим доступу: https://ukrlit.net/info/dict/5yef1.html

6. Хомченкова Е.А. Феноменология гениальности: от антропной к социокультурной детерминации: Автореф. дис ... канд. філос. наук: 09.00.13. Омск, 2007. 20 с.

7. Ball L.C. The Genius in History: Historiographic Explorations. The Wiley handbook of genius. Oxford: Wiley Blackwell, 2014. P. 3-19.

8. Conceptual metaphor. URL: http://scodis.com/for-students/ glossary/ conceptual-metaphor/ 
9. Kövecses, Zoltán. Conceptual metaphor theory. URL: https://www.researchgate.net/publication/311403391_Conceptual_metaphor_ theory/citation/download

10. Ritchie L.D. Conceptual Metaphor Theory. Context and Connection in Metaphor. Palgrave Macmillan, London.URL: https://link.springer.com/chapter/10.1057/9780230286825_3

11. Genius. URL: https://www.brainyquote.com/topics/genius

12. Genius: articles. URL: https://www.nationalgeographic.com/ search?q=genius

13. Albert Einstein. URL: http://www.notablebiographies.com/DuFi/Einstein-Albert.html\#ixzz4WVvnakf8

14. Isaac Newton. URL: https://www.biography.com/news/isaacnewton-biography-facts

15. Leonardo da Vinci. URL: http://www.biography.com/people/ leonardo-da-vinci-40396\#the-last-supper

16. Wolfgang Amadeus Mozart. URL: https://www.biography.com/ people/wolfgang-mozart-9417115

17. Roald Dahl. Matilda. URL: http://jssisdubai.com/document/ uploaded/matilda.pdf

\section{Information about the author:}

Strochenko L. V.,

Candidate of Philological Sciences, Associate Professor at the Chair of Lexicology and Stylistics of the English Language, Odesa I. I. Mechnikov National University 2, Dvoryanska str., Odesa, 65082, Ukraine 